\title{
Feasibility of Marine Microalgae Immobilization in Alginate Bead for Marine Water Treatment: Bead Stability, Cell Growth, and Ammonia Removal
}

\author{
Chen-Lin Soo, ${ }^{1,2}$ Cheng-Ann Chen, ${ }^{3}$ Othman Bojo, ${ }^{2}$ and Yii-Siang Hii ${ }^{1}$ \\ ${ }^{1}$ School of Fisheries and Aquaculture Sciences, Universiti Malaysia Terengganu, 21030 Kuala Terengganu, Terengganu, Malaysia \\ ${ }^{2}$ Faculty of Resource Science and Technology, Universiti Malaysia Sarawak, 94300 Kota Samarahan, Sarawak, Malaysia \\ ${ }^{3}$ Borneo Marine Research Institute, Universiti Malaysia Sabah, Jalan UMS, 88400 Kota Kinabalu, Sabah, Malaysia
}

Correspondence should be addressed to Chen-Lin Soo; qianlin1112@gmail.com

Received 16 August 2017; Revised 10 October 2017; Accepted 19 October 2017; Published 13 November 2017

Academic Editor: Guocheng Zhu

Copyright (C) 2017 Chen-Lin Soo et al. This is an open access article distributed under the Creative Commons Attribution License, which permits unrestricted use, distribution, and reproduction in any medium, provided the original work is properly cited.

\begin{abstract}
Sodium alginate is the most commonly used polymer matrix in microalgae immobilization for water treatment. However, the susceptibility of alginate matrixes to cation chelating agents and antigelling cation limits the use of alginates in estuarine and marine systems. Hence, the present study aims to investigate the stability of alginate bead in marine water and the feasibility of microalgae to grow when immobilized in alginate bead for marine water treatment. Different concentrations of alginate and hardening cation calcium were used to formulate beads. The beads were incubated in Guillard's f/2 medium and shaken vigorously by using orbital shaker for 15 days. The results indicated that bead stability was enhanced by increasing alginate and $\mathrm{CaCl}_{2}$ concentrations. Subsequently, the marine microalga, Nannochloropsis sp., was immobilized in calcium alginate bead. The growth and ammoniacal-nitrogen $\left(\mathrm{NH}_{4}^{+}-\mathrm{N}\right)$ uptake by immobilized cell were compared with free cell culture in f/2 medium. Specific growth rate of immobilized cell $\left(0.063 \mathrm{hr}^{-1}\right)$ was significantly higher than free cell $\left(0.027 \mathrm{hr}^{-1}\right)$. There was no significant difference on specific uptake rate of free cell and immobilized cell; but immobilized cell removed significantly more $\mathrm{NH}_{4}{ }^{+}-\mathrm{N}(82.2 \%)$ than free cell $(47.3 \%)$ culture at the end of the experiment. The present study demonstrated the potential use of alginate immobilization technique in marine microalgae culture and water treatment simultaneously.
\end{abstract}

\section{Introduction}

Sodium alginate is the most commonly used polymer matrix for microalgae immobilization [1]. The immobilized microalgae have been exploited for removing nutrient in wastewater $[2,3]$ and have great potential to be used in marine aquaculture wastewater treatment. Effluents from aquaculture are rich in solids and dissolved nutrients, mainly in the form of inorganic nitrogen and phosphorus [4, 5]. Effluents from aquaculture industry should be treated before discharge into its adjacent aquatic ecosystem to avoid eutrophication and water contamination. Hence, cultivation of immobilized microalgae in aquaculture water offers the advantages of nutrients removal from water as microalgae grow; the immobilization also solves the restriction of harvesting microalgae from the treatment system at the same time [6].
However, the major limitation for the use of alginate gel entrapment for microalgae in marine system is the instability of calcium alginate gel upon contact with cation chelating agents and antigelling cations [1,7]. Knowledge on bead stability is needed since stability is directly related to its performance and limitations in many applications. The properties of calcium alginate gel have been widely studied and numerous efforts have been made to increase the bead stability [8]. However, as far as we are aware, studies on bead stability in seawater are relatively scarce.

In order to apply immobilized microalgae for nutrient removal in marine aquaculture, the stability of alginate bead in marine system should be of great concern. As stability problems in marine system have been resolved, this immobilization technique will be a promising tool in marine microalgae immobilization. One of the simplest and 
effective ways to enhance bead stability is by amending the alginate and cation concentrations. The gelation and mechanical properties of alginate gel depend strongly on the composition and concentration of alginate and on the cation and polycation used as gel-inducing agent [7,9]. The hypothesis is that the stability of alginate bead can be improved by increasing the alginate and cation concentrations. For this, different concentrations of alginate and hardening cations calcium were used to formulate beads. The ultimate goal of this study was to produce alginate beads stable in seawater.

Nannochloropsis sp. is a unicellular marine alga commonly cultivated in fish hatcheries as feed for rotifers and to create a "green-water" in fish larvae tanks. The nutritional value of Nannochloropsis makes it well appreciated in aquaculture $[10,11]$. Immobilized cell provided greater resistance to toxicity, better operational stability, and enhanced nutrient removal rate $[1,12]$. The algae biomass can be further exploited as a life feed and a valuable biochemical source for feed preparation in aquaculture industry [13]. The hypothesis is that the marine alga Nannochloropsis sp. can be immobilized in alginate bead and is able to grow after immobilization. Hence, the second part of this study aims to focus on the feasibility to immobilize Nannochloropsis sp. in alginate bead. The growth rate and ammoniacal-nitrogen $\left(\mathrm{NH}_{4}{ }^{+}-\mathrm{N}\right)$ uptake rate of immobilized Nannochloropsis sp. were compared with free cell culture. The removal of ammoniacal-nitrogen was focused in the present study as ammoniacal-nitrogen is the major waste product excreted by fish and toxic to fish in high concentration. The stability of alginate bead with immobilized cell was also assessed in the present study.

\section{Materials and Methods}

2.1. Preparation of Calcium Alginate Bead. Calcium alginate bead was prepared as described by [14] with minor modification. Firstly, alginate solution was prepared by slow stirring of sodium alginate (Fisher Scientific) in warmed distilled water and then autoclaved at $121^{\circ} \mathrm{C}$ and $15 \mathrm{psi}$ pressure for 20 minutes. The sterile alginate solution was added dropwise into $\mathrm{CaCl}_{2}$ solution from a height of $2.5 \mathrm{~cm}$ above by using a peristaltic pump (MASTERFLEX) at a rate of one drop per second. The $4 \mathrm{~mm}$ beads formed were kept stirred in the $\mathrm{CaCl}_{2}$ solution for $30 \mathrm{~min}$ to allow complete hardening of the alginate. The beads were washed several times to eliminate the remaining $\mathrm{CaCl}_{2}$. A known volume of alginate beads was counted to determine the number of beads formulated. Approximately 3000 beads were produced from $100 \mathrm{ml}$ of alginate solution.

2.2. Nannochloropsis sp. Nannochloropsis sp. was obtained from the marine microalgae stock culture in the Universiti Malaysia Terengganu (UMT), Malaysia. The culture was maintained under standard culture condition as described in [15] where the culture was supplied with a continuous illumination under a constant light intensity of $100 \mu \mathrm{mol} \mathrm{m}^{-2} \mathrm{~s}^{-1}$ and maintained at $28^{\circ} \mathrm{C}$, salinity $30 \mathrm{ppt}, \mathrm{pH} 8$, in the Guillard's f/2 medium [16].

\subsection{Experimental Design}

2.3.1. Experiment 1. To study the effect of alginate concentration on beads stability, four concentrations of alginate solution which are $10 \mathrm{gL}^{-1}, 30 \mathrm{gL}^{-1}, 40 \mathrm{gL}^{-1}$, and $60 \mathrm{gL}^{-1}$ were used to prepare beads as described above by using a $10 \mathrm{~g} \mathrm{~L}^{-1} \mathrm{CaCl}_{2}$ solution as hardening cation. For alginate hardening, five concentrations of $\mathrm{CaCl}_{2}$ solution which are $3 \mathrm{~g} \mathrm{~L}^{-1}, 10 \mathrm{~g} \mathrm{~L}^{-1}, 20 \mathrm{gL}^{-1}, 30 \mathrm{gL}^{-1}$, and $40 \mathrm{~g} \mathrm{~L}^{-1}$ were used to study the effect of $\mathrm{CaCl}_{2}$ concentration on beads stability. In this study, $30 \mathrm{~g} \mathrm{~L}^{-1}$ alginate solution was used to prepare bead. The stability of the beads was tested by incubating the beads in the Guillard's f/2 medium [16] in a $50 \mathrm{ml}$ conical flask. The flask was positioned randomly on an orbital shaker (250 rpm) under abovementioned standard culture condition for 15 days. Three replicates, with $10 \mathrm{ml}$ of alginate beads in $30 \mathrm{ml}$ of $f / 2$ medium ( $1: 3$ ratios), were used per treatment. At each sampling time, ten beads of each treatment were taken to test the stability of beads. The diameter of the beads was measured by using a digital caliper (GERE), to monitor bead swelling or shrinkage, which were considered as signs of alginate instability. A bead type was considered fully unstable when more than $10 \%$ of the total mean number of beads lost their spherical shape due to alginate disruption or dissolution [17].

2.3.2. Experiment 2. Free cell and immobilized cell cultures of Nannochloropsis sp. were prepared. Firstly, an aliquot of exponentially growing Nannochloropsis sp. was harvested by centrifugation at $1542 \times \mathrm{g}$ for 15 minutes. The cells were washed twice and concentrated in pasteurized seawater. The cell density was determined by a spectrophotometer (UV-160, SHIMADZU) at $600 \mathrm{~nm}$ and calculated from the standard curve of optical density-Nannochloropsis sp. (Figure 1). For free cell culture, a selected volume of the concentrated Nannochloropsis sp. cell suspension was mixed with the $\mathrm{f} / 2$ medium. An initial cell density of $1.3 \times 10^{6} \mathrm{cells} \mathrm{m}^{-1}$ was used in the present study. For immobilized cell culture, a selected volume of the concentrated Nannochloropsis sp. cell suspension ( $\leq 1 \mathrm{ml} / 100 \mathrm{ml}$ of alginate solution) was thoroughly mixed with $50 \mathrm{~g} \mathrm{~L}^{-1}$ alginate solution to obtain an alginatecell suspension with a cell density of $2 \times 10^{7}$ cells ml $^{-1}$ of alginate solution. The number of cells in the alginate solution was counted by a Neubauer improved hemocytometer. The calcium alginate bead was prepared as described above by using a $20 \mathrm{~g} \mathrm{~L}^{-1} \mathrm{CaCl}_{2}$ solution as hardening cation. Approximately 3000 beads were produced from $100 \mathrm{ml}$ of alginate solutions with an initial cell density of $3.5 \times 10^{5}$ cells bead $^{-1}$. Batch cultures of free cell and alginate immobilized cell were grown in the Guillard's $\mathrm{f} / 2$ medium under abovementioned standard culture condition in triplicate. 1:3 ratios of bead and $f / 2$ medium were used. Both cultures were positioned randomly on an orbital shaker (250 rpm). The $\mathrm{pH}$ value was recorded with a $\mathrm{pH}$ meter (WTW SERIES) and maintained at $\mathrm{pH} 8-\mathrm{pH} 10$ with $0.01 \mathrm{M}$ sterilized $\mathrm{HCl}$ throughout the experiment.

At each sampling time, $40 \mathrm{ml}$ of water samples was taken from free cell culture while $5 \mathrm{ml}$ of beads and $15 \mathrm{ml}$ of water samples were taken from immobilized cell culture. For free 


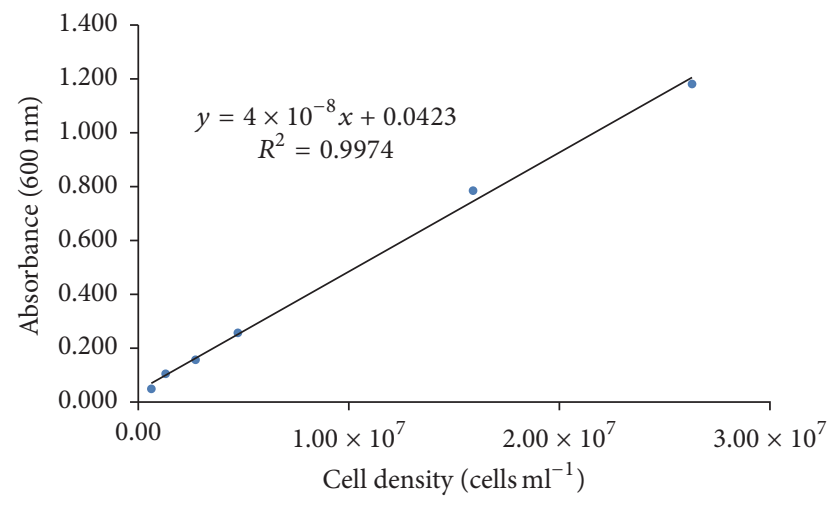

FIgURE 1: The standard curve of optical density-Nannochloropsis sp.

cell culture, cell density was determined spectrophotometrically at $600 \mathrm{~nm}$. Quality control of the optical density method was conducted. In brief, random samples of the experiment were chosen and the number of cells was counted by a Neubauer improved hemocytometer and then compared with cell density determined spectrophotometrically. More than $90 \%$ recovery of cell density was obtained throughout the experiment. Water sample was centrifuged and the clear supernatant was used to determine $\mathrm{NH}_{4}{ }^{+}$-N concentration. For immobilized cell culture, the number of cells in the beads was counted by a Neubauer improved hemocytometer after dissolving 10 alginate beads (with known volume) in a $0.5 \mathrm{M}$ trisodium citrate solution (with known volume). The method of [18] was used to determine $\mathrm{NH}_{4}{ }^{+}-\mathrm{N}$ concentration. The experiment lasted at 240 hours and 216 hours for free and immobilized cell cultures, respectively. At the end of the experiment, the diameter of the beads was measured by using a digital caliper (GERE). The water sample from the immobilized cell culture was centrifuged to determine the cell leakage of the bead.

2.4. Data and Statistical Analysis. The initial diameter, final diameter, and percentage changes of beads produced by different concentrations of alginate and $\mathrm{CaCl}_{2}$ solution were compared using a one-way ANOVA, followed by a Tukey' test to verify the differences. An independent $t$-test was used to compare the initial and final diameters of beads after 15 days of incubation for each treatment. The specific growth rate (SGR) and specific uptake rate (SUR) of free and immobilized cell were obtained by a linear regression of the logistic model following Jimenez-Perez et al. [19] as below:

$$
\ln \left(\frac{K}{(N t)}-1\right)=a-b t
$$

where $K$ is the maximum cell attained (cell ml ${ }^{-1}$ and cell bead $^{-1}$ in free and immobilized cell cultures, resp.) or maximum $\mathrm{NH}_{4}{ }^{+}-\mathrm{N}$ uptake $(\mu \mathrm{M})$ in the culture, $N t$ is the cell density (cell ml ${ }^{-1}$ and cell bead ${ }^{-1}$ in free and immobilized cell cultures, resp.) or $\mathrm{NH}_{4}{ }^{+}-\mathrm{N}$ concentration $(\mu \mathrm{M})$ at time $t, a$ is the intercept, and $b$ is the specific growth rate $\left(\mathrm{hr}^{-1}\right)$ or specific uptake rate $\left(\mathrm{hr}^{-1}\right)$.
The maximum cell attained, SGR, maximum $\mathrm{NH}_{4}{ }^{+}-\mathrm{N}$ uptake, and SUR of free and immobilized cell were compared using an independent $t$-test. All the statistical analyses were carried out by using the Statistical Software for Social Sciences (SPSS Version 22, SPSS Inc., 1995).

\section{Results and Discussion}

3.1. Bead Stability in Marine Water. In the present study, different concentrations of alginate and $\mathrm{CaCl}_{2}$ solutions were used to produce alginate bead. Sphere-shaped bead cannot be formed by using a $10 \mathrm{gL}^{-1}$ alginate concentration or hardening by a $3 \mathrm{~g} \mathrm{~L}^{-1} \mathrm{CaCl}_{2}$ solution. Figure 2 illustrates that the bead size increased significantly ( $p$ value $\leq 0.05$ ) when alginate concentration increased whereas the bead size decreased significantly ( $p$ value $\leq 0.05$ ) when $\mathrm{CaCl}_{2}$ solution increased. All beads demonstrated shrinkage in size when incubated in marine water (Figure 3 ). However, bead stability increased by increasing alginate and $\mathrm{CaCl}_{2}$ concentrations. The stability of bead formed by using $30 \mathrm{~g} \mathrm{~L}^{-1}$ alginate and hardening by using $10 \mathrm{gL}^{-1} \mathrm{CaCl}_{2}$ was the lowest among the beads. The diameter of bead decreased $7.52 \%$ from its initial size after 15 days of incubation. The most stable bead was formed by using $60 \mathrm{~g} \mathrm{~L}^{-1}$ alginate and hardening by $20 \mathrm{~g} \mathrm{~L}^{-1} \mathrm{CaCl}_{2}$ solution which decreased by $3.14 \%$ and $5.14 \%$, respectively.

Concentrations of alginate and $\mathrm{CaCl}_{2}$ solutions represent the fundamental parameters in immobilization technique. It varied depending on the substance to be immobilized and the purpose of the immobilization. Moreira et al. [17] showed that beads prepared by using a $4.9 \%$ alginate extracted from Laminaria hyperborea and hardened with a $4 \%(\mathrm{w} / \mathrm{v})$ cation solution were found to be the most stable in seawater and the most suitable for Phaeodactylum tricornutum growth. Those authors showed that beads hardened using $4 \%$ rather than $2 \%$ of calcium or strontium solutions were found to be more stable. Won et al. [20] pointed out that alginate concentration was important for lipase entrapment in Ca-alginate beads while $\mathrm{CaCl}_{2}$ concentration had less effect on it. Idris and Suzana [21] showed that the maximum concentration of lactic acid was produced by immobilized Lactobacillus delbrueckii when $2 \%$ of sodium alginate concentration was used.

On top of calcium, the use of other divalent cations presenting high affinity for alginate, and polycations, namely, chitosan, has been proposed to enhance bead stability $[17,22$, 23]. However, the use of suitable divalent cations is largely restricted by its toxicity to cells. Bajpai and Sharma [22] demonstrated that the barium ion cross-linked beads possessed greater stability than calcium alginate beads. However, the toxicity of barium ions makes calcium ions a preferential divalent cation. Although alginate bead with chitosan hardening treatment showed higher stability [24], immobilized Phaeodactylum tricornutum with chitosan hardening treatment showed a weak growth performance [17]. Those authors attributed the weak growth performance to the occurrence of growth limiting conditions for the microalgae within the alginate matrix. As the end goal of our study was to produce more stable alginate beads immobilized with microalgae for application in marine water treatment, the mild procedure 


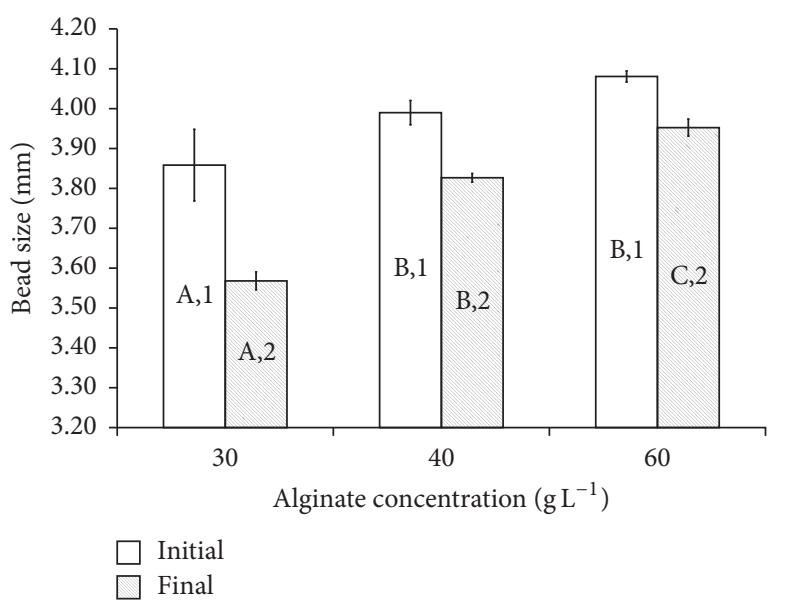

(a)

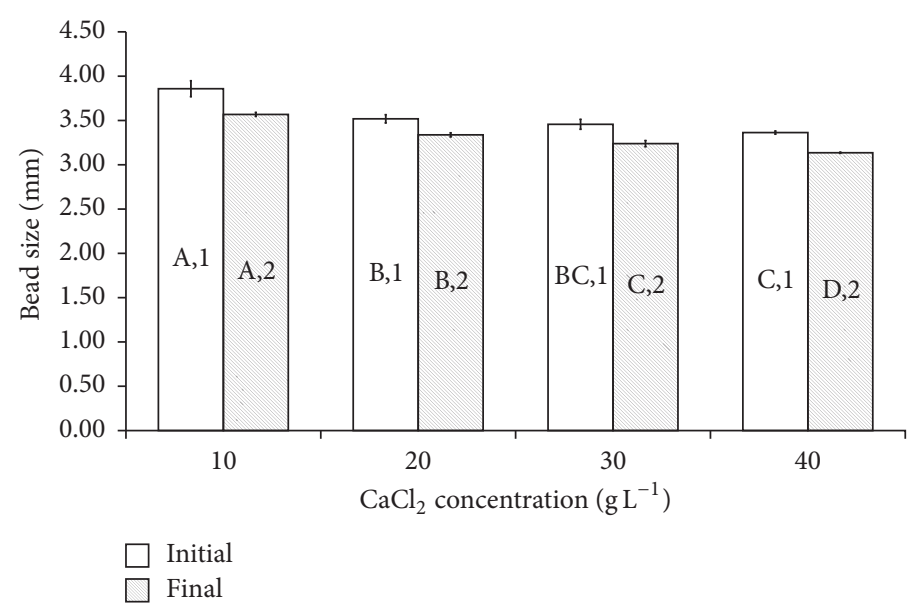

(b)

FIGURE 2: The diameter $(\mathrm{mm})$ of alginate bead during initial and final incubation periods. The different letter at each initial and final period indicated significant difference ( $p$ value $\leq 0.05$ ) between alginate beads prepared by using different (a) alginate concentrations and (b) hardening by different concentrations of $\mathrm{CaCl}_{2}$ solution. The different number at each treatment indicated that initial size of alginate bead is significantly different $(p$ value $\leq 0.05)$ from final size of bead.

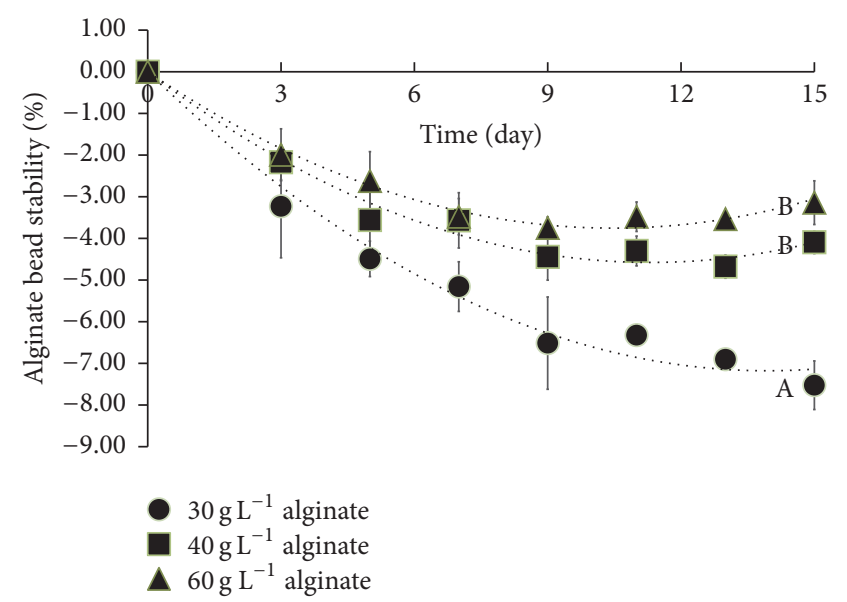

(a)

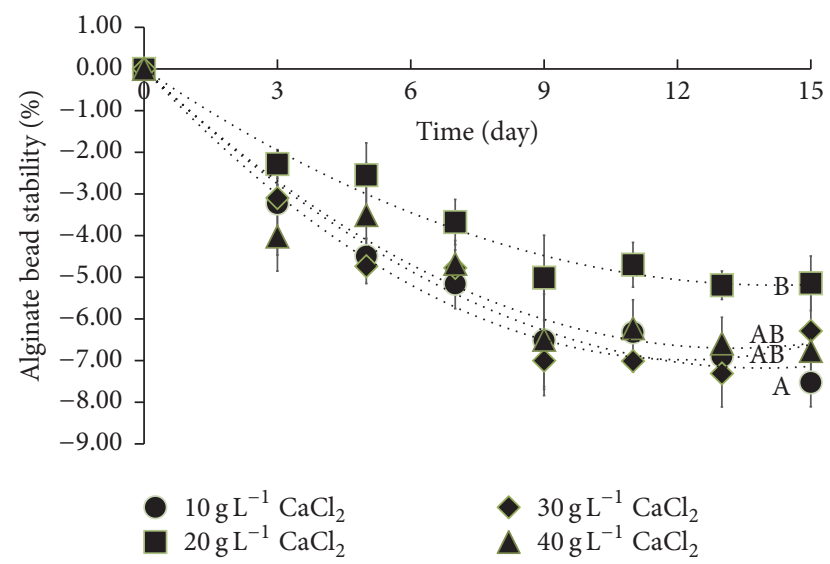

(b)

FIGURE 3: Changes (\%) of alginate bead prepared by using different (a) alginate concentrations and (b) hardening by different concentrations of $\mathrm{CaCl}_{2}$ solution in $\mathrm{f} / 2$ medium for 15 days. The different letter indicated significant difference $(p$ value $\leq 0.05)$ between alginate bead prepared by using different (a) alginate concentrations and (b) hardening by different concentrations of $\mathrm{CaCl}_{2}$ solution at the end of the experiment.

of immobilization technique by using alginate and $\mathrm{CaCl}_{2}$ solutions was the most suitable method.

\subsection{Performance of Free and Immobilized Nannochloropsis} $s p$. Cultures. Figure 4 illustrates the growth curves for free and immobilized cells of Nannochloropsis sp. showing the high viability of the cell after immobilized in calcium alginate bead. The SGR and SUR of free and immobilized cells were $0.027 \pm 0.002 \mathrm{hr}^{-1}, 0.032 \pm 0.021 \mathrm{hr}^{-1}, 0.063 \pm 0.022 \mathrm{hr}^{-1}$, and $0.025 \pm 0.002 \mathrm{hr}^{-1}$, respectively (Table 1 ). The SGR of immobilized cell was significantly higher $(p$ value $=0.046)$ than free cell although the maximum cell attained by free cell culture $\left(6.1 \times 10^{6} \pm 3.8 \times 10^{4}\right.$ cells ml $\left.^{-1}\right)$ was significantly higher $(p$ value $=0.000)$ than immobilized cell $\left(8.2 \times 10^{5} \pm\right.$ $3.8 \times 10^{4}$ cells bead $\left.^{-1}\right)$. The immobilized cell consumed 798.7 \pm
$28.6 \mu \mathrm{M}$ of $\mathrm{NH}_{4}{ }^{+}-\mathrm{N}$ with an uptake efficiency of $82.2 \%$ at the end of the experiment. The maximum $\mathrm{NH}_{4}{ }^{+}-\mathrm{N}$ consumed by immobilized cell was significantly higher $(p$ value $=0.002)$ than free cell culture which consumed $374.7 \pm 90.7 \mu \mathrm{M}$ of $\mathrm{NH}_{4}{ }^{+}-\mathrm{N}$ with an uptake efficiency of $47.3 \%$. Figure 4 illustrates that the $\mathrm{NH}_{4}{ }^{+}-\mathrm{N}$ uptake by free cell culture had ceased at stagnant phase but immobilized cell continued to consume $\mathrm{NH}_{4}{ }^{+}-\mathrm{N}$ at the stagnant phase. Nevertheless, there was no significant difference ( $p$ value $>0.05$ ) on the SUR of $\mathrm{NH}_{4}{ }^{+}-\mathrm{N}$ between free and immobilized cell cultures. The alginate bead immobilized with Nannochloropsis sp. remained stable after being incubated in seawater for 216 hours (Table 2). The problem of cell leakage was negligible with a cell leakage of $0.22 \%$. It was found that an increase in the concentration of alginate and $\mathrm{CaCl}_{2}$ gives rise to a 


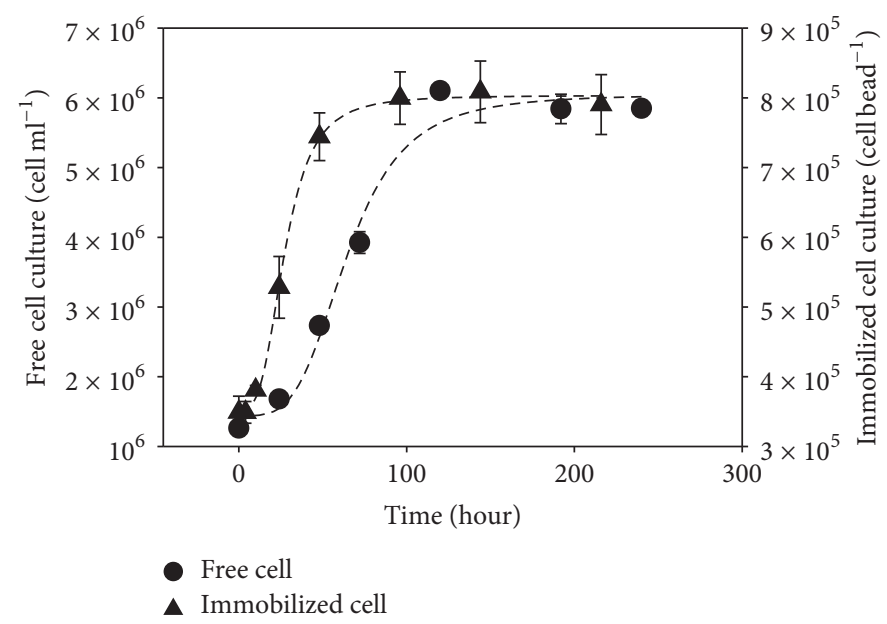

(a)

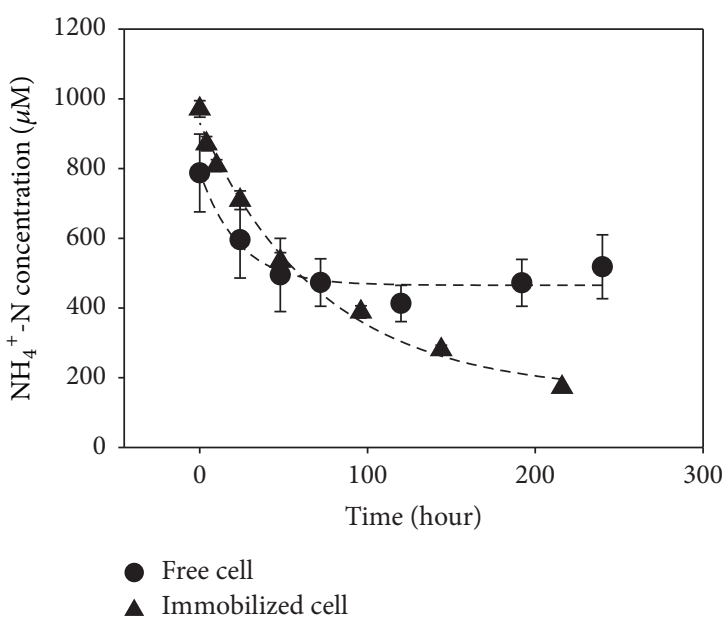

(b)

FIGURE 4: (a) Growth and (b) $\mathrm{NH}_{4}{ }^{+}$-N uptake of free and immobilized cell incubated in $\mathrm{f} / 2$ medium enriched with $900 \mu \mathrm{M} \mathrm{NH}{ }_{4}^{+}-\mathrm{N}$. Markers are mean and vertical bars showed standard deviation with $n=3$.

TABLE 1: Summary of the results and $t$-test of free and immobilized cell incubated in $\mathrm{f} / 2$ medium enriched with $900 \mu \mathrm{M} \mathrm{NH}{ }_{4}^{+}-\mathrm{N} . n=3$.

\begin{tabular}{lccccc}
\hline \multirow{2}{*}{ Parameter } & \multicolumn{2}{c}{ Free cell } & \multicolumn{2}{c}{ Immobilized cell } & \multicolumn{2}{c}{$\begin{array}{c}\text {-test } \\
\end{array}$} & Mean & SD & $8.2 \times 10^{5}$ & $4.3 \times 10^{4}$ & $\mathbf{0 . 0 0 0}$ \\
\hline Maximum cell attained & $6.1 \times 10^{6}$ & $3.8 \times 10^{4}$ & 0.063 & 0.022 & $\mathbf{0 . 0 4 6}$ \\
SGR & 0.027 & 0.002 & 798.7 & 28.6 & $\mathbf{0 . 0 0 2}$ \\
Maximum $\mathrm{NH}_{4}{ }^{+}$-N consumed & 374.7 & 90.7 & 0.025 & 0.002 & 0.612 \\
SUR & 0.032 & 0.021 & & & \\
\hline
\end{tabular}

Significant value of $p$ value $\leq 0.05$ is indicated in bold.

TABLE 2: The stability of microalgae immobilized bead and percentage of cell leakage.

\begin{tabular}{|c|c|c|c|c|c|c|c|c|c|}
\hline \multicolumn{2}{|c|}{ Initial bead size $(\mathrm{mm})$} & \multicolumn{2}{|c|}{ Initial bead size $(\mathrm{mm})$} & \multirow{2}{*}{$\begin{array}{c}\text { Bead changes } \\
(\%)\end{array}$} & \multicolumn{2}{|c|}{$\begin{array}{l}\text { Total immobilized cell } \\
\qquad(100 \mathrm{ml})\end{array}$} & \multicolumn{2}{|c|}{$\begin{array}{l}\text { Total cell leached } \\
\quad(300 \mathrm{ml})\end{array}$} & \multirow{2}{*}{$\begin{array}{c}\text { Cell leakage } \\
(\%)\end{array}$} \\
\hline Mean & $\mathrm{SD}$ & Mean & SD & & Mean & SD & Mean & SD & \\
\hline 4.04 & 0.06 & 4.05 & 0.04 & 0.26 & $2.4 \times 10^{9}$ & $1.3 \times 10^{8}$ & $5.2 \times 10^{6}$ & $1.1 \times 10^{6}$ & 0.22 \\
\hline
\end{tabular}

reduction in the leakage of enzyme, glucose oxidase [25]. The insignificant cell leakage in the present study indicates that the use of $50 \mathrm{~g} \mathrm{~L}^{-1}$ of alginate solution and $20 \mathrm{~g} \mathrm{~L}^{-1}$ of $\mathrm{CaCl}_{2}$ solution as hardening cation is sufficient for Nannochloropsis sp. immobilization in alginate bead.

The result demonstrated that immobilization did not affect the growth of cells. Similarly, Jimenez-Perez et al. [19] demonstrated similar growth of free and immobilized cells in Scenedesmus intermedius and Nannochloris sp. Pane et al. [26] also demonstrated higher viability of the Tetraselmis suecica after immobilization in calcium alginate gel. The immobilized T. suecica demonstrated similar growth pattern with the present immobilized Nannochloropsis sp. although it was inoculated with a lower initial cell density of $6.0 \times$ $10^{4}$ cells bead $^{-1}$ when compared to the present study $(3.5 \times$ $10^{5}$ cells bead $\left.^{-1}\right)$. However, the free cell culture of $T$. suecica showed longer initial lag phase ( $>6$ days) than the present study ( $<2$ days) after inoculation. The shorter lag phase of Nannochloropsis sp. than T. suecica is most probably due to the higher initial cell density of Nannochloropsis sp. $(1.3 \times$
$10^{6}$ cells $\left.\mathrm{ml}^{-1}\right)$ than $T$. suecica $\left(1.3 \times 10^{5}\right.$ cells $\left.\mathrm{ml}^{-1}\right)$. In the present study, Nannochloropsis sp. is able to remove $\mathrm{NH}_{4}{ }^{+}-\mathrm{N}$ in $\mathrm{f} / 2$ medium. The high removal efficiency of immobilized cultures is presumably because of the increased cell density where a $1: 3$ ratios of alginate bead and $f / 2$ medium were used, despite the low initial cell density $\left(5 \times 10^{5}\right.$ cells bead $\left.^{-1}\right)$ in alginate bead. The low initial cell density in alginate bead is to avoid cell leaching problem during treatment. Nevertheless, by manipulating the quantity of alginate bead used in the water treatment system, the efficiency of nutrient removal will be greatly improved as higher algal bead concentration suggested more algal cells for removing nutrients.

\section{Conclusions}

The present study demonstrated that the increase of alginate and $\mathrm{CaCl}_{2}$ concentrations retarded the shrinkage of beads in marine water. Alginate beads prepared by using $60 \mathrm{~g} \mathrm{~L}^{-1}$ alginate solution hardening by $20 \mathrm{~g} \mathrm{~L}^{-1} \mathrm{CaCl}_{2}$ were found to be the most stable beads incubated in an $\mathrm{f} / 2$ medium, 
demonstrating its potential use in marine system. Immobilization of the marine microalgae, Nannochloropsis sp. in alginate beads, did not affect the growth of Nannochloropsis $\mathrm{sp}$. The specific growth rate and maximum $\mathrm{NH}_{4}{ }^{+}-\mathrm{N}$ uptake of the immobilized cell were markedly higher than free cell. The present study showed that the immobilized Nannochloropsis sp. can be a potential biological treatment for aquaculture water where the algae biomass can be further exploited as life feed and valuable biochemical source for feed preparation.

\section{Conflicts of Interest}

The authors declare that there are no conflicts of interest regarding the publication of this paper.

\section{Acknowledgments}

The authors would like to thank Ministry of Science, Technology and Innovation (MOSTI), Malaysia, for funding this study through e-Science Project 05-01-12-SF0001.

\section{References}

[1] I. Moreno-Garrido, "Microalgae immobilization: current techniques and uses," Bioresource Technology, vol. 99, no. 10, pp. 3949-3964, 2008.

[2] L. E. de-Bashan and Y. Bashan, "Immobilized microalgae for removing pollutants: Review of practical aspects," Bioresource Technology, vol. 101, no. 6, pp. 1611-1627, 2010.

[3] E. Zhang, B. Wang, Q. Wang, S. Zhang, and B. Zhao, "Ammonia-nitrogen and orthophosphate removal by immobilized Scenedesmus sp. isolated from municipal wastewater for potential use in tertiary treatment," Bioresource Technology, vol. 99, no. 9, pp. 3787-3793, 2008.

[4] Y. Thomas, C. Courties, Y. El Helwe, A. Herbland, and H. Lemonnier, "Spatial and temporal extension of eutrophication associated with shrimp farm wastewater discharges in the New Caledonia lagoon," Marine Pollution Bulletin, vol. 61, no. 7-12, pp. 387-398, 2010.

[5] T. D. Bui, J. Luong-Van, and C. M. Austin, "Impact of shrimp farm effluent on water quality in coastal areas of the world heritage-listed Ha Long Bay," American Journal of Environmental Sciences, vol. 8, no. 2, pp. 104-116, 2012.

[6] J. C. M. Pires, M. C. M. Alvim-Ferraz, F. G. Martins, and M. Simões, "Wastewater treatment to enhance the economic viability of microalgae culture," Environmental Science and Pollution Research, vol. 20, no. 8, pp. 5096-5105, 2013.

[7] I. Cruz, Y. Bashan, G. Hernàndez-Carmona, and L. E. DeBashan, "Biological deterioration of alginate beads containing immobilized microalgae and bacteria during tertiary wastewater treatment," Applied Microbiology and Biotechnology, vol. 97, no. 22, pp. 9847-9858, 2013.

[8] M. R. De Boisseson, M. Leonard, P. Hubert et al., "Physical alginate hydrogels based on hydrophobic or dual hydrophobic/ionic interactions: Bead formation, structure, and stability," Journal of Colloid and Interface Science, vol. 273, no. 1, pp. 131139, 2004.

[9] S. Roger, D. Talbot, and A. Bee, "Preparation and effect of Ca2+ on water solubility, particle release and swelling properties of magnetic alginate films," Journal of Magnetism and Magnetic Materials, vol. 305, no. 1, pp. 221-227, 2006.
[10] L. M. Lubián, O. Montero, I. Moreno-Garrido et al., "Nannochloropsis (Eustigmatophyceae) as source of commercially valuable pigments," Journal of Applied Phycology, vol. 12, no. 3-5, pp. 249-255, 2000.

[11] L. Krienitz and M. Wirth, "The high content of polyunsaturated fatty acids in Nannochloropsis limnetica (Eustigmatophyceae) and its implication for food web interactions, freshwater aquaculture and biotechnology," Limnologica, vol. 36, no. 3, pp. 204210, 2006.

[12] S. A. Covarrubias, L. E. De-Bashan, M. Moreno, and Y. Bashan, "Alginate beads provide a beneficial physical barrier against native microorganisms in wastewater treated with immobilized bacteria and microalgae," Applied Microbiology and Biotechnology, vol. 93, no. 6, pp. 2669-2680, 2012.

[13] M. A. Borowitzka, "Microalgae for aquaculture: Opportunities and constraints," Journal of Applied Phycology, vol. 9, no. 5, pp. 393-401, 1997.

[14] Y.-C. Chen, "Immobilized microalga Scenedesmus quadricauda (Chlorophyta, Chlorococcales) for long-term storage and for application for water quality control in fish culture," Aquaculture, vol. 195, no. 1-2, pp. 71-80, 2001.

[15] Y. S. Hii, C. L. Soo, T. S. Chuah, A. Mohd-Azmi, and A. B. Abol-Munafi, "Interactive effect of ammonia and nitrate on the nitrogen uptake by Nannochloropsis sp," Journal of Sustainability Science and Management, vol. 6, no. 1, pp. 60-68, 2011.

[16] L. L. Smith, J. M. Fox, and D. R. Granvil, "Intensive algae culture techniques," in RC Handbook of Mariculture. Volume 1. Crustacean Aquaculture, J. P. McVey, Ed., pp. 3-13, CRC Press, Boca Raton, Fla, USA, 2nd edition, 1993.

[17] S. M. Moreira, M. Moreira-Santos, L. Guilhermino, and R. Ribeiro, "Immobilization of the marine microalga Phaeodactylum tricornutum in alginate for in situ experiments: Bead stability and suitability," Enzyme and Microbial Technology, vol. 38, no. 1-2, pp. 135-141, 2006.

[18] T. R. Parsons, Y. Maita, and C. M. Lalli, A Manual of Chemical and Biological Methods for Seawater Analysis, Pergamon Press, Oxford, UK, 1984.

[19] M. V. Jimenez-Perez, P. Sánchez-Castillo, O. Romera, D. Fernández-Moreno, and C. Pérez-Martínez, "Growth and nutrient removal in free and immobilized planktonic green algae isolated from pig manure," Enzyme and Microbial Technology, vol. 34, no. 5, pp. 392-398, 2004.

[20] K. Won, S. Kim, K. Kim, H. W. Park, and S. Moon, "Optimization of lipase entrapment in Ca-alginate gel beads," Process Biochemistry, vol. 40, no. 6, pp. 2149-2154, 2005.

[21] A. Idris and W. Suzana, "Effect of sodium alginate concentration, bead diameter, initial $\mathrm{pH}$ and temperature on lactic acid production from pineapple waste using immobilized Lactobacillus delbrueckii," Process Biochemistry, vol. 41, no. 5, pp. 1117-1123, 2006.

[22] S. K. Bajpai and S. Sharma, "Investigation of swelling/degradation behavior of alginate beads cross-linked with $\mathrm{Ca}^{2+}$ and $\mathrm{Ba}^{2+}$ ions," Reactive and Functional Polymers, vol. 59, no. 2, pp. 129140, 2004.

[23] S. K. Bajpai and R. Tankhiwale, "Investigation of water uptake behavior and stability of calcium alginate/chitosan bi-polymeric beads: part-1," Reactive and Functional Polymers, vol. 66, no. 6, pp. 645-658, 2006.

[24] W.-T. Kim, H. Chung, I.-S. Shin, K. L. Yam, and D. Chung, "Characterization of calcium alginate and chitosan-treated calcium alginate gel beads entrapping allyl isothiocyanate," Carbohydrate Polymers, vol. 71, no. 4, pp. 566-573, 2008. 
[25] A. Blandino, M. Maćas, and D. Cantero, "Glucose oxidase release from calcium alginate gel capsules," Enzyme and Microbial Technology, vol. 27, no. 3-5, pp. 319-324, 2000.

[26] L. Pane, M. Feletti, C. Bertino, and A. Carli, "Viability of the marine microalga Tetraselmis suecica grown free and immobilized in alginate beads," Aquaculture International, vol. 6, no. 6, pp. 411-420, 1998. 

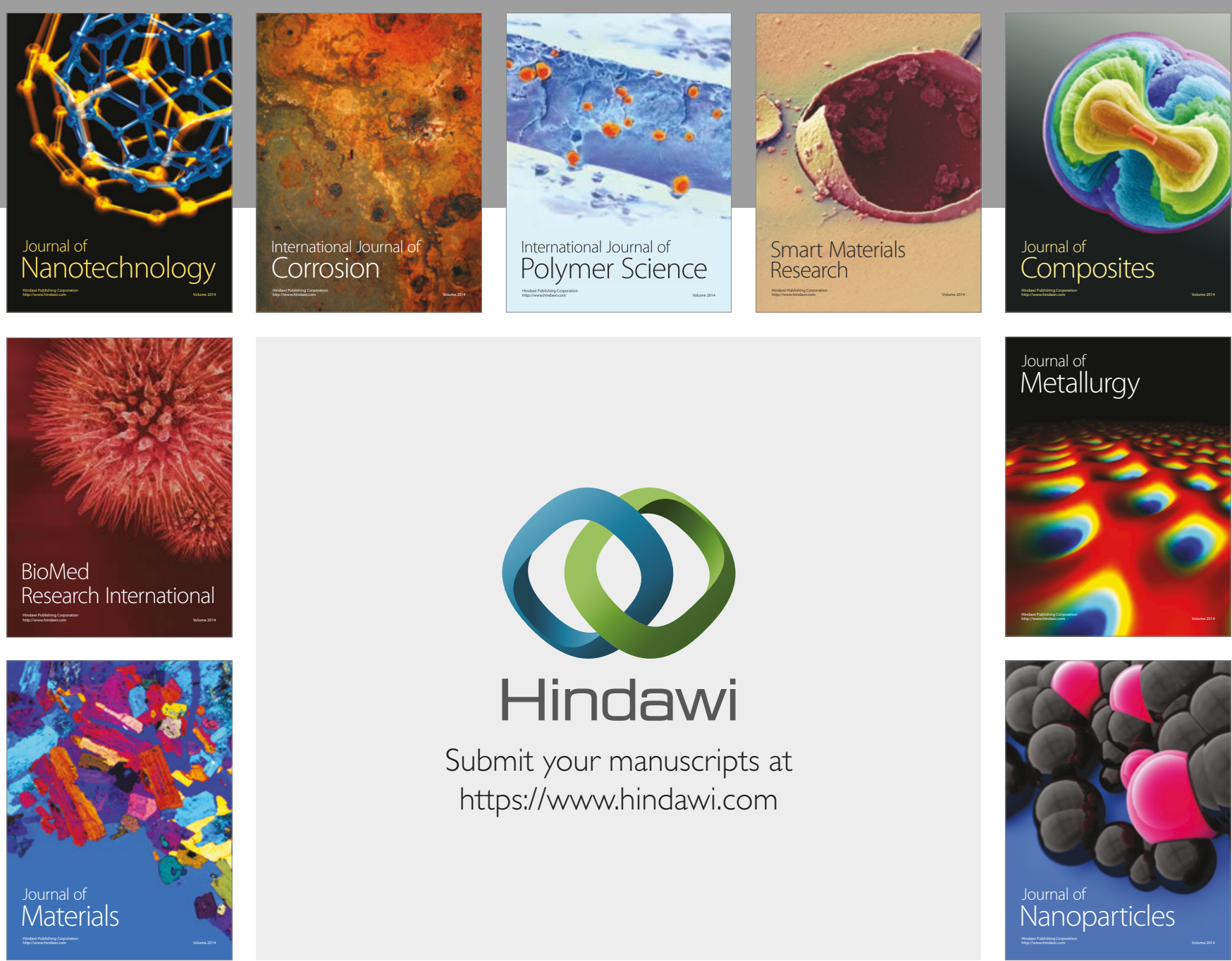

\section{Hindawi}

Submit your manuscripts at

https://www.hindawi.com
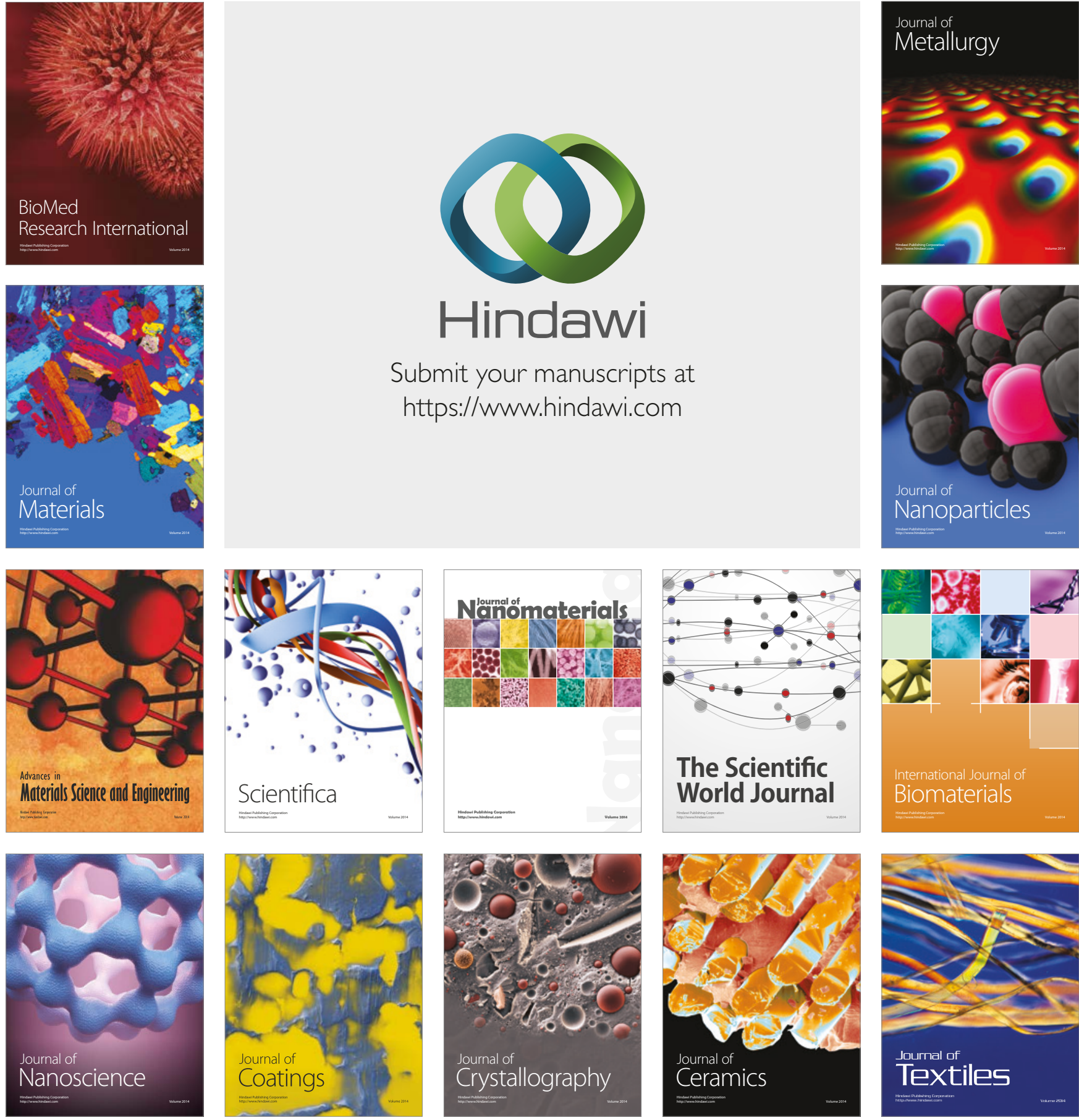

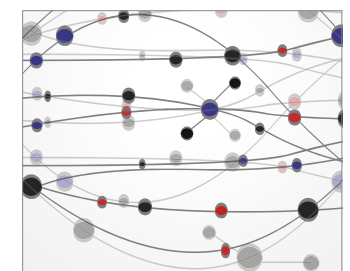

The Scientific World Journal
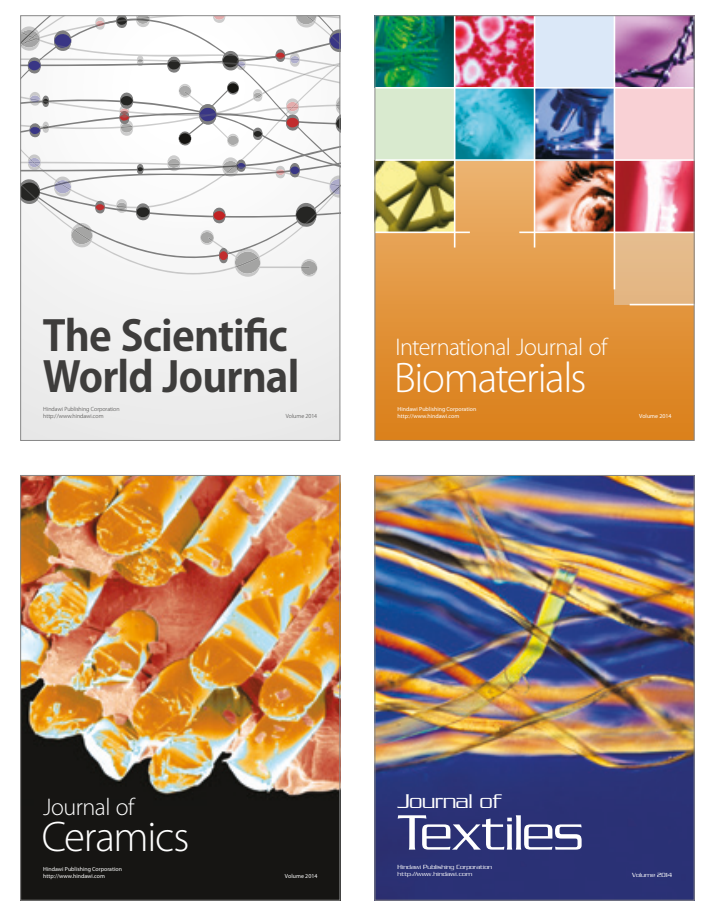